\title{
Pemaafan Pada Penyintas Kekerasan Seksual Dalam Berpacaran Ditinjau Dari Big-Five Personality
}

\author{
Arthur Huwae \\ Fakultas Psikologi Universitas Kristen Satya Wacana \\ email:arthurhuwae92@gmail.com
}

\section{Artikel INFO}

Diterima:04 Oktober 2020

Direvisi: 15 Desember 2020

Disetujui: 22 Februari 2021

DOI:

http://dx.doi.org/10.24014/ jp.v14i2.10900

\section{Abstrak}

\begin{abstract}
Kekerasan seksual dalam berpacaran (KSDB) sering kali terjadi dan banyak merugikan perempuan sebagai korban. Keadaan ini merupakan salah satu kasus yang membuat para korban mengalami penderitaan yang sangat serius dari segi fisik, psikologis, maupun sosial, dan bahkan tidak sedikit yang berakhir pada kematian. Untuk bisa bangkit dan pulih dari kisah buruknya, maka individu perlu memiliki dan membentuk kepribadian yang baik, sehingga mengarahkannya pada penerapan pemaafan yang penuh pada pelaku dan menjadikan hidupnya lebih berarti. Penelitian ini bertujuan mengetahui hubungan antara dimensi big five personality dengan pemaafan pada penyintas KSDB. Metode dalam penelitian ini menggunakan kuantitatif korelasi yang melibatkan 48 partisipan, dengan teknik purposive sampling. Pengumpulan data menggunakan skala big five personality dan skala pemaafan KSDB. Hasil analisis data menunjukkan terdapat hubungan positif signifikan antara dimensi big five personality dan pemaafan KSDB dengan nilai sig. $=0,000(p<0,05)$. Untuk merasa tenang, aman, dan nyaman, maka individu mampu belajar memaafkan dan berdamai dengan kisah buruk dari KSDB yang ia alami, dan individu juga belajar melakukan tindakan positif kepada pelaku. Hal ini membuatnya mampu mencapai pemulihan psikologis yang optimal.
\end{abstract}

Kata Kunci : Pemaafan, big five personality, kekerasan seksual dalam berpacaran.

\section{Forgiveness On Sexual Violence Survivor In Dating Reviewed From Big Five Personality}

\begin{abstract}
Sexual Violence in Dating (SVD) often occurs and does much harm to woman as a victims. This condition is one of the cases in which victims suffer extreme physical, psychological, and social suffering, and not even a fraction of which end in death. In order to recorver from the bad story, an individual needs to have and shape a good personality so as to direct his or her use of the full forgiveness of the perpetrator, thus making his or her life more meaningful. The study aims to know the relationship between the big five personality dimensions and the forgiving of the SVD survivors. The methods of this study uses quantitative correlation that involved 48 participants, using an purposive sampling as a sampling technique.The data is collected used the big five personality scale and the forgiveness of sexual assault on relationship scale. Data analysis shows a significant positive relationship with an sig. $=0,000(p<0,05)$. To be calm, safe, and comfortable, a survivor should able to forgive and make peace with the bad story of violence in dating and learn to keep up the good relationship with the perpetrator, and the survivors also learn to perform positive action on the perpetrator. This allows the survivors to achieve optimum psychological recovery.
\end{abstract}

Keywords : Forgiveness, big five personality, sexual violence in dating

\section{Pendahuluan}

Pacaran merupakan salah satu bagian yang terjadi di dalam proses pertumbuhan dan perkembangan manusia. Individu yang menjalin hubungan berpacaran, cenderung berada pada usia setelah masa puber (Hays, Michel, Cole, Emelianchik, Forman, Lorelle, McBride, \& Sikes, 2011 ; Santrock, 2016 ; Huwae, 2020). Untuk menjalin hubungan 
berpacaran, setiap individu memiliki kriteria khusus seperti dari tampilan fisik, gaya hidup, finansial, peminatan, dan pembawaan diri (Munroe, 2004 ; Berk, 2014). Kriteria ini yang memicu daya tarik individu tersebut untuk mengungkapkan perasaan kepada orang yang ia cintai.

Saat menjalani hubungan, setiap pasangan belajar untuk mengenal pasangannya. Proses pengenalan yang semakin dalam, sering kali membuat individu menganggap kehidupan pasangan adalah keutuhan miliknya (Waring \& Barraket, 2008), sehingga keinginan tersebut sering membuat ia bertindak lebih terhadap pasangan (Zahab, Dharmawan, \& Winarni, 2017). Apabila tindakan ini tidak dikontrol dengan baik, akan berdampak buruk pada hubungan jangka panjang, dan berakibat pada konflik (Ohee \& Purnomo, 2018). Kemudian, konflik yang terjadi merujuk pada tindak kekerasan yang dilakukan di antara pasangan (McDonell, Ott, \& Mitchell, 2010 ; Nurifah, 2013).

Kekerasan dalam berpacaran (KDB) sampai saat ini masih terus terjadi pada pasangan remaja atau muda-mudi. Hal ini karena di usia tersebut, seseorang akan mudah meluapkan perasaan yang ia miliki kepada pasangannya sebagai wujud cinta lewat pegangan tangan, berpelukan, berciuman, bahkan berhubungan seks (Borrajo, Guadix, \& Calvete, 2015 ; Huwae, 2020). Permasalahan KDB biasa dilakukan oleh laki-laki kepada perempuan sebagai korban dengan berbagai bentuk tindak kekerasan, dan sering dilakukan berulang kali.

Dilansir dari National Commission on Violence Against Women (2020), bahwa tindak KDB setiap tahun terus mengalami peningkatan. Bentuk kekerasan yang dialami korban biasanya bervariasi, bahkan ada juga yang mengalami secara berlapis mulai dari kekerasan fisik, vebal, seksual, dan pengabaian (Hamby, 2017). Kekerasan dalam berpacaran yang dianggap paling berisiko terhadap patologi mental ialah kekerasan seksual, karena bentuk kekerasan ini sering bersamaan dengan kekerasan yang lainnya (Smith, Nunley, \& Martin, 2013).

Berdasarkan hasil asesmen (self-report) dari korban kekerasan seksual dalam berpacaran (KSDB), dijumpai bahwa korban mendapat perlakuan yang kurang baik dari pasangan. Hubungan pacaran yang terjalin tampak tidak sehat, karena perlakuan yang diberi oleh pelaku terasa manyakitkan. Korban dituntut dan dipaksa untuk melakukan hubungan seks layaknya suamiistri, serta diikuti dengan cacian / hinaan, pukulan, maupun tendangan. Peristiwa ini membuat luka batin yang sangat dalam, dan membutuhkan proses yang panjang bagi korban untuk bisa pulih kembali. Bahkan, terkadang trauma tersebut masih terus terlintas di pikiran dan perasaan korban setiap kali ia ingin membuka diri untuk membangun hubungan yang baru.

Keadaan yang dialami korban, juga diperkuat dari data National Commission on Violence Against Women (2020), bahwa pada tahun 2020 kekerasan terhadap perempuan yang paling menonjol sama seperti tahun sebelumnya adalah KDRT/RP (ranah personal) yang mencapai 75\% (11.105 kasus). Ranah pribadi paling banyak dilaporkan dan tidak sedikit diantaranya mengalami kekerasan seksual, termasuk di dalamnya hubungan berpacaran. Meskipun demikian, pendampingan serta pemulihan korban terus ditingkatkan dengan berbagai bentuk pendekatan dari segi hukum, sosial, medis, maupun psikologis (National Commission on Violence Against Women, 2020).

Susanti, Husni, \& Fitriyani (2014), mengungkapkan bahwa perasaan terluka, persepsi terhadap ketidakadilan, serta perilaku yang tidak diharapkan, menyebabkan seseorang bisa marah dan berdampak pada penghancuran diri. Jika dilihat, KSDB yang terjadi membuat korban memiliki tingkat kecurigaan yang tidak wajar terhadap orang lain, dan terhambat dalam menjalani hubungan sosial. Keadaan lain yang juga dirasakan oleh korban ialah, ia akan memandang diri rendah, putus asa, depresi, dan bahkan 
tidak sedikit yang ingin membalas dendam terhadap pelaku, serta muncul pikiran untuk bunuh diri (WHO, 2002 ; Crandall, Schwab, Sheehan, \& Esposito, 2010). Permasalahan seperti ini secara keseluruhan akan semakin memperburuk keadaan korban. Untuk itu, individu yang ingin menjalani kehidupan lebih baik dari sebelumnya, maka ia harus mampu berdamai dengan kisah tersebut, salah satu yaitu dengan membangun konsep pemaafan terhadap pelaku KSDB.

Pemaafan atau yang biasa disebut forgiveness, merupakan suatu dorongan secara psikologis berkaitan dengan kognitif, afektif, dan psikomotor pada individu yang merasa diperlakukan dengan kurang baik yang berdampak buruk pada setiap aspek kehidupan, guna memberi pengampunan atas setiap kesalahan yang diperbuat oleh orang lain kepadanya (McClullough, 2000). Menurut Feeney (2011), individu yang mampu keluar dari perasaan terluka dan peristiwa yang menyakitkan, menjadikan ia sebagai pribadi yang punya harapan baru untuk bisa pulih, karena ia belajar melepaskan dan membuang semua kebencian maupun rasa sakit hati yang selama ini dipendam. Tingginya nilai pemaafan yang dibentuk oleh individu, mengarah pada kemampuan bertahan untuk menghadapi kesulitan atau masalah hidup, sehingga dapat mencapai kreativitas dan kecerdasan diri (Lijo, 2008). Meskipun demikian, perlu diketahui bahwa pembentukan pemaafan KSDB berbeda dengan beberapa kasus yang lain, dimana individu memerlukan waktu dan proses bertahap yang mendalam.

Pattiradjawane, Wijono, \& Engel (2019), menegaskan bahwa pemaafan dapat digunakan sebagai salah satu bentuk pemulihan psikologi bagi setiap orang yang telah menjadi korban kekerasan. Begitu juga menurut Natasya \& Susilawati (2020), bahwa pemaafan dapat dijadikan sebagai sarana alternatif untuk membantu korban memulihkan keadaan. Dengan demikian, untuk membentuk dan mengembangkan pemaafan dari KSDB yang dialami, maka individu memerlukan beberapa komponen yang mampu dijadikan sebagai kekuatan diri (McCullough, 2000). Komponen pertama yaitu avoidance motivations, dimana individu tetap menjalin relasi dengan pelaku, namun mengurangi intensitas kontak secara langsung. Kedua yaitu revenge motivations, dimana individu secara afeksi belajar membuang rasa benci dan keinginan akan balas dendam terhadap pelaku. Ketiga yaitu benevolence motivations, dimana individu tetap berbuat kebajikan akan kepeduliannya terhadap pelaku.

Chung (2016), dalam penelitiannya menggambarkan tentang individu yang sulit menerapkan pemaafan, cenderung mengalami depresi berkelanjutan karena memiliki belas kasihan diri yang rendah. Di sisi lain, McCullough \& Witvliet (2001), yang mengkaji mengenai pemaafan untuk mencapai kesejahteraan psikologis, mengungkapkan bahwa orang yang selalu belajar memaafkan perlakuan buruk yang ia terima dari orang lain, akan lebih bahagia dan mencapai kepuasan spiritual. Pandangan ini sejalan dengan yang disampaikan oleh Frankl (1992), bahwa individu yang dapat memaafkan dan berdamai dengan pengalaman hidup yang buruk, akan mampu untuk melihat harapan-harapan positif dibalik penderitaan yang ia alami, dan akan lebih mudah untuk mengaktualisasi diri secara penuh.

Terealisasinya pemaafan korban KSDB kepada pelaku tidak terlepas dari banyak faktor, salah satunya yaitu faktor kepribadian (Worthington \& Wade, 1999). Faktor kepribadian yang sangat erat pengaruhnya terhadap pemaafan yaitu the big five. Big five merupakan salah satu pendekatan psikologi yang digunakan untuk menggambarkan kepribadian manusia secara komprehensif melalui trait yang tersusun dalam lima besar dimensi kepribadian yang telah dibentuk dengan menggunakan analisis faktor, yaitu ekstraversion, agreeableness, conscientiousness, neuroticism, dan openness to experience (McCrae \& Costa, 1997). Penggambaran dimensi big five pada diri seseorang, terlihat pada seberapa kuat sisi kepribadian (positif/negatif) yang ia tunjukkan kepada lingkungan sekitar (McCrae \& Costa, 
1997).

Bhattacharyya, Suresh, \& Joan (2015), menindaklanjutin bahwa individu yang mempunyai sifat ekstraversion tinggi, mudah untuk membangun relasi, serta mampu untuk aktif dan tegas menelaah setiap hal buruk yang ia alami sebagai proses belajar. Tingkat agreeableness yang tinggi, menuntun individu untuk mampu berempati dan menempatkan diri dengan hangat. Selanjutnya, individu yang memiliki tingkat conscientiousness tinggi, menjadikan ia sebagai pribadi yang mampu mempertimbangkan segala sesuatu dengan bijak. Begitu juga dengan tingkat openness to experience yang tinggi, membantu individu lebih proaktif dalam memahami dan menerima diri sendiri maupun orang lain. Sedangkan untuk neuroticism, individu harus mengarahkannya pada area positif, sehingga ia mampu mengendalikan emosi negatif yang ada dalam diri (Bhattacharyya, dkk., 2015 ; Walker \& Gorsuch, 2002).

Dampak dari pemaafan sendiri sangat besar bagi kelangsungan hidup individu yang menjadi korban KSDB, dimana ia dapat membangkitkan semangat baru dalam beraktivitas, dan memiliki tujuan hidup yang lebih positif (Farhadiasl \& Pakdaman, 2016). Meskipun demikian, kondisi ini harus disertai dengan kepribadian yang baik pula dari individu tersebut, sehingga akan lebih mudah bagi ia untuk menerapkan pemaafan di setiap aspek kehidupannya.

Dari Hasil penelitian yang dilakukan oleh Hafnidar (2013), nampak bahwa dimensi big five memiliki hubungan dengan pemaafan. Penelitian lain yang dilakukan oleh Abid, Shafiq, Naz, \& Riaz (2015), menunjukkan ada hubungan positif empat dimensi big five dengan pemaafan, sedangkan dimensi neuroticismberhubungan negatif. Selanjutnya, dari hasil studi literatur yang dikaji oleh Lijo (2008), ditemukan bahwa masih kurangnya eksplorasi kesehatan mental akan karakter pribadi dengan sikap memaafkan.

Beranjak dari permasalahan yang terjadi dan kajian penelitian yang ada sebelumnya, secara spesifik masih rendahnya pembentukan kepribadian secara optimal, yang menyebabkan korban KSDB tidak berdaya untuk bangkit dari penderitaan yang ia alami. Maka dari itu, penelitian ini bertujuan untuk mengetahui keterikatan antara dimensi big five personality dengan pemaafan KSDB. Sedangkan hipotesis penelitiannya adalah, terdapat hubungan signifikan antara dimensi big five personality dengan pemaafan KSDB.

\section{Metode}

\section{Desain dan Partisipan Penelitian}

Penelitian ini menggunakan desain kuantitatif korelasional untuk melihat hubungan antara dimensi big five personality dengan pemaafan KSDB. Teknik purposive sampling digunakan untuk memeroleh partisipan dengan kriteria, yaitu : perempuan perantauan berusia antara 18-22 tahun yang pernah mengalami KSDB, dan sudah pernah melakukan konseling psikologi maupun konseling pastoral. Dipilihnya kriteria tersebut, karena berdasarkan pandangan Santrock (2016), di usia remaja akhir menuju dewasa awal, individu diperhadapkan pada tanggung jawab dan realita hidup yang semakin besar dari segi pola pikir, perasaan, akademik, persiapan karir, peran sosial, hubungan pertemanan / persahabatan, percintaan, dan persiapan untuk berkeluarga. Dengan demikian, terdapat 48 partisipan yang terlibat dalam penelitian ini dengan menandatangani lembar inform consent.

\section{Pengukuran}

Skala pengukuran dalam penelitian ini terdiri dari skala big five personality dan skala pemaafan KSDB. Pilihan jawaban yang digunakan mengacu pada model Likert yang terdiri dari empat, yaitu : sangat sesuai (SS), sesuai (S), tidak sesuai (TS), dan sangat tidak sesuai (STS) (Azwar, 2012). Selanjutnya, standar nilai seleksi aitem $(p \geq 0,30)$ dan reliabilitas $(\alpha=0,8)$ yang digunakan, berpatokan pada sudut pandang Azwar (dalam Huwae, 2020). 
Big five personality yaitu ekstraversion, agreeableness, conscientiousness, neuroticism, dan openness to experience (McCrae \& Costa, 1997), diukur menggunakan big five inventory (BFI : John, 1990), yang kemudian dimodifikasi sesuai dengan karakteristik partisipan, sehingga terdapat 25 aitem. Salah satu contoh aitem dari skala ini adalah "refleksi diri membuat saya dapat mengubah hidup menjadi lebih baik". Dari pengujian, diperoleh kisaran nilai seleksi aitem sebesar $0,331-0,758$, dan tingkat reliabilitas skala sebesar 0,938 yang tergolong sangat reliabel.

Untuk data pemaafan KSDB, diukur menggunakan interpersonal forgiveness scale dari McCullough, Worthington, \& Rachal (1997), yang kemudian dimodifikasi berdasarkan tiga komponen pemaafan yaitu, avoidance motivations, revenge motivations,

\section{Hasil}

Tabel 1 : Demografi Partisipan Penelitian

\begin{tabular}{ccccccccc}
\hline \multicolumn{3}{c}{ Asal Daerah } & \multicolumn{4}{c}{ Karakteristik Usia } & \multicolumn{3}{c}{$\begin{array}{c}\text { Banyaknya KSDB yang } \\
\text { Dialami }\end{array}$} \\
\hline Asal & $\mathbf{F}$ & $\mathbf{\%}$ & Usia & $\mathbf{F}$ & $\mathbf{\%}$ & Jumlah & $\mathbf{F}$ & $\%$ \\
\hline Papua & 9 & $18,75 \%$ & 18 tahun & 8 & $16,67 \%$ & 1 kali & 10 & $20,83 \%$ \\
Maluku & 9 & $18,75 \%$ & 19 tahun & 10 & $20,83 \%$ & 2 kali & 13 & $27,08 \%$ \\
Sulawesi & 6 & $12,5 \%$ & 20 tahun & 13 & $27,08 \%$ & 3 kali & 11 & $22,92 \%$ \\
NTT & 10 & $20,83 \%$ & 21 tahun & 8 & $16,67 \%$ & 4 kali & 6 & $12,5 \%$ \\
Kalimantan & 4 & $8,33 \%$ & 22 tahun & 9 & $18,75 \%$ & $>4$ kali & 8 & $16,67 \%$ \\
Jawa & 5 & $10,42 \%$ & & & & & & \\
Sumatera & 5 & $10,42 \%$ & & & & & & \\
\hline Total & $\mathbf{4 8}$ & $\mathbf{1 0 0} \%$ & & $\mathbf{4 8}$ & $\mathbf{1 0 0 \%}$ & & $\mathbf{4 8}$ & $\mathbf{1 0 0 \%}$ \\
\hline
\end{tabular}

Dari data demografi pada tabel 1, menggambarkan keterlibatan partisipan dari tujuh wilayah yang ada di Indonesia, yaitu dari Papua 9 orang $(18,75 \%)$, Maluku 9 orang $(18,75 \%)$, Sulawesi 6 orang $(12,5 \%)$, Nusa Tenggara Timur (NTT) 10 orang $(20,83 \%)$, Kalimantan 4 orang $(8,33 \%)$, Jawa 5 orang $(10,42 \%)$, dan Sumatera 5 orang $(10,42 \%)$. Dari segi usia, keterlibatan partisipan berusia 18 tahun sebanyak 8 orang $(16,67 \%)$, usia 19 tahun 10 orang $(20,83 \%)$, usia 20 tahun 13 orang $(27,08 \%)$, usia 21 tahun 8 orang $(16,67 \%)$, dan usia 22 tahun 9 orang $(18,75 \%)$. Kemudian, dari banyaknya tindak KSDB yang dialami, terdapat 10 orang yang mengalami dan benevolence motivations (McCullough, 2000), dan disesuaikan dengan karakteristik partisipan, sehingga terdapat 24 aitem. Salah satu contoh aitem dari skala ini adalah "saya ingin tetap melakukan tindakan positif kepadanya". Dari pengujian, diperoleh nilai seleksi aitem yang berkisar antara 0,3000,690 , dengan tingkat reliabilitas skala sebesar 0,906 yang tergolong sangat reliabel.

\section{Analisis Data}

Pengujian data penelitian menggunakan uji normalitas, uji linieritas, korelasi product moment dari Karl Pearson, dan uji deskriptif statistik untuk melihat gambaran kategorisasi serta sumbangan efektif (Creswell, 2010). Semua pengujian data akan menggunakan bantuan program SPSS seri 21.0 for windows. 
Sedangkan pada variabel pemaafan KSDB, nilai K-S-Z sebesar 0,908 dan sig. $=0,382$. Dengan demikian, kedua variabel ini dapat dikatakan berdistribusi normal.

Hasil Uji Hipotesis

Tabel 2 : Uji Korelasi

\section{Uji Linieritas}

Dari hasil uji linieritas, diperoleh nilai $F_{\text {hitung }}$ sebesar 121,548 dan sig. $=0,000$ $(p<0,05)$ yang menunjukkan hubungan antara faktor big five personality dengan pemaafan pada penyintas KSDB adalah linier.

\begin{tabular}{llcc}
\hline & Nilai $\mathbf{r}$ & $\begin{array}{c}\text { Sig } \\
(\mathbf{P}<\mathbf{0 , 0 5})\end{array}$ & Ket. \\
\hline Ekstraversion dan pemaafan KSDB & $.834^{* *}$ & .000 & Ada Hubungan \\
Agreeableness dan pemaafan KSDB & $.744^{* *}$ & .000 & Ada Hubungan \\
Conscientiousness dan pemaafan KSDB & $.730^{* *}$ & .000 & Ada Hubungan \\
Neuroticism dan pemaafan KSDB & $.734^{* *}$ & .000 & Ada Hubungan \\
$\begin{array}{l}\text { Openness to experience dan pemaafan } \\
\text { KSDB }\end{array}$ & $.741^{* *}$ & .000 & Ada Hubungan \\
\hline
\end{tabular}

Dari hasil pengujian hipotesis pada tabel 2, menunjukkan bahwa :

1. Terdapat hubungan positif signifikan antara dimensi ekstraversion dengan pemaafan KSDB ( $r=0,834$ dan sig.= 0,000).

2. Terdapat hubungan positif signifikan antara dimensi agreeableness dengan pemaafan KSDB ( $r=0,744$ dan sig.= 0,000).

3. Terdapat hubungan positif signifikan antara dimensi conscientiousness dengan pemaafan KSDB ( $r=0,730$ dan sig. $=0,000$ ).

4. Terdapat hubungan positif signifikan antara dimensi neuroticism dengan pemaafan KSDB ( $r=0,734$ dan sig.= 0,000 ).

5. Terdapat hubungan positif signifikan antara dimensi openness to experience dengan pemaafan KSDB ( $r=0,741$ dan sig. $=0,000)$.

Hasil Sumbangan Efektif

Tabel 3 : Sumbangan Efektif Faktor Big Five Personality Terhadap Pemaafan KSDB Faktor Big Five Personality

Extraversion

Agreeableness Sumbangan Efektif

Concientiouness $17,5 \%$

$14 \%$

Neuroticism

$13,3 \%$

$13,5 \%$

Openness to Experience

$13,7 \%$

\section{Total}

$\mathbf{7 2 \%}$


Berdasarkan sumbangan efektif faktor big five personality terhadap pemaafan KSDB pada tabel 3, diperoleh hasil sebesar $72 \%$, yang menunjukkan bahwa big five personality merupakan salah satu faktor yang sangat besar pengaruhnya terhadap pemaafan penyintas KSDB. Besarnya sumbangan faktor big five personality terhadap pemaafan, memberikan pandangan bagi setiap orang termasuk penyintas KSDB bahwa perubahan hidup yang lebih sehat yang terjadi, tergantung dari cara masing-masing individu membentuk dan menerapkan kepribadian yang baik di dalam hidupnya.

\section{Pembahasan}

Dari hasil penelitian membuktikan bahwa hipotesis diterima, dan big five perso-nality memberikan sumbangan efektif sebesar $72 \%$, yang berarti faktor dari dalam diri penyintas KSDB, yakni kepribadian sangat besar peranannya terhadap tindakan individu untuk memberikan pemaafan kepada pelaku. Tingginya big five personality merupakan salah satu faktor yang berhubungan secara signifikan terhadap meningkatnya pemaafan. Adanya hubungan positif yang signifikan disebabkan karena tingginya big five personality yang dimiliki oleh penyintas yang merupakan bagian dari prinsip pemaafan yang dilakukan, yang turut menentukan kelanjutan hidupnya (Chung, 2007). Selain itu, hasil ini mendukung penelitian yang dilakukan oleh Hafnidar (2013), dan Abid, dkk. (2015), dimana penerapan pemaafan tidak terlepas dari peran besar kepribadian yang dimiliki oleh individu itu sendiri.

Waring dan Barraket (2008), mengungkapkan bahwa individu yang memiliki komitmen tinggi meskipun telah mengakhiri hubungan percintaan dengan pelaku, akan selalu menjaga relasi sebagai makhluk sosial dengan tetap mengutamakan keamanan dan kenyamanan diri. Hal ini bermakna bahwa individu yang sekalipun mendapatkan tindak kekerasan dari pelaku, belajar untuk memberi pengampunan karena begitu besar kepeduliannya terhadap kesehatan fisik dan mental (Hurley \& Weber, 2012). Nampak juga individu yang memiliki karakter yang baik secara pembawaan, keterbukaan, kehangatan, serta pemahaman yang baik, cenderung memaafkan tindakan kekerasan yang ia pernah terima dari pelaku selama proses berpacaran (Munroe, 2004). Selain itu, penyintas KSDB memiliki tingkat neuroticism ke arah positif, sehingga menjadikan ia lebih baik dalam mengendalikan emosi. Dengan pengontrolan emosi yang baik, individu cenderung mampu menyelesaikan masalah, salah satunya dengan pemberian pemaafan secara total (Kaleta \& Mroz, 2018). Seperti yang diungkapkan oleh Walker \& Gorsuch (2002), dalam penelitiannya, bahwa kepribadian neurotisme mengenai stabilitas emosi berkorelasi dengan sikap memaafkan, serta faktor kepribadian membantu dalam memahami sikap memaafkan disposisional.

Hasil penelitian ini memberikan pandangan bahwa dalam keadaan terburuk yang dialami, individu masih memiliki sisi baik yakni terus membangun dan membentuk pemaafan dengan konsep cinta kasih akan ketulusan, sehingga berdampak baik pada kelangsungan hidup selanjutnya, baik secara personal maupun sosial. Dengan terbentuknya pemaafan, individu juga mampu memaknai proses hidupnya untuk mencapai kedamaian, kepuasan, dan kebahagiaan (Muhid, Khariroh, Fauziyah, \& Andiarna, 2019). Individu yang merasakan kehangatan dan kebahagiaan diri adalah ketika ia mampu menerapkan pemaafan sebagai bentuk pemulihan psikologis secara menyeluruh, dan berusaha membuang pengalaman buruk yang pernah ia alami (McCullough, 2000).

Kategori pemaafan yang tinggi, menggambarkan rerata partisipan dominan telah belajar untuk tidak menjadikan pengalaman buruk KSDB merusak aktivitas positif yang saat ini sedang dijalani. Partisipan juga belajar untuk tidak menyimpan rasa kekecewaan, kepahitan, permusuhan, dan kebencian dari KSDB yang ia dapatkan, serta mencoba untuk menerima keadaan diri, mencintai diri sendiri maupun orang lain dengan konsep keikhlasan. Kemudian, partisipan juga berusaha untuk menghilangkan keinginan 
balas dendam terhadap pelaku, dan memiliki keinginan untuk melakukan kebaikan kepada pelaku. Tujuan partisipan menerapkan konsep ini, karena partsipan ingin memperbaiki dan menjalani kehidupan baru yang lebih baik dan sehat. Semua keputusan maupun tindakan positif partisipan, nyatanya didukung dari hasil proses konseling psikologi maupun pastoral yang pernah dilakukan, sehingga dirasa membantu dalam membentuk kepribadian yang baik guna untuk memulihkan keadaan psikologis partisipan.

Santrock (2016), mengatakan bahwa di setiap tahapan perkembangan, individu akan selalu menghadapi fase krisis termasuk di dalamnya hubungan percintaan. Dalam hubungan percintaan, akan selalu ada masalah seperti tindakan kekerasan yang dilakukan oleh pasangan. Untuk itu, individu yang mampu menghadapi keadaan psikologis yang berat, akan cenderung menggambarkan kekuatan diri yang tinggi (Ulfah,2016). Hal ini karena individu memiliki self-report yang baik, dimana ia mampu menelaah setiap peristiwa buruk yang terjadi, dan bisa menemukan cara tepat kemudian menerapkannya guna untuk mencapai welas diri yang positif (Balliet, 2010). Dengan diterapkannya pemaafan dari peristiwa-peristiwa buruk yang dialami oleh individu, maka secara bertahap akan melatih individu tersebut untuk mengembangkan positive mindset, serta menunjukkan kemajuan hidup yang positif (Harmaini \& Yulianti, 2014).

Kehidupan yang berarti / berharga adalah ketika individu yang merasa diri diperlakukan dengan tidak baik termasuk pengalaman kekerasan, mampu untuk menyelesaikan dengan cara membangun kekuatan mental yang positif, sehingga kehidupan yang dijalani saat ini akan berdampak pada peningkatan setiap harapan yang ingin dicapai kedepan (Hamby, 2017). Pattiradjawane, dkk. (2019), turut mengungkapkan bahwa pengoptimalisasian hidupyang sehat, adalahketikaindividumampu berdamai dan terbuka akan pembaharuan diri, serta mau menghadapi setiap realita hidup. Begitu juga yang disampaikan oleh
Hafnidar (2013), bahwa individu yang mampu belajar memperbaiki dan menata kehidupan yang pahit dengan melakukan terobosan untuk pembentukan kepribadian yang baik, akan lebih mudah menerapkan pemaafan, sehingga tidak menghambatnya untuk meraih prestasi hidup.

Dengan demikian, setiap orang menginginkan pemulihan psikologis melalui penerapan pemaafan terhadap setiap masalah hidup yang terjadi dengan tetap membentuk kepribadian ke area positif, yang berdampak pada keberfungsian hidup secara penuh dan mencapai kesehatan mental yang optimal.

\section{Kesimpulan}

Kesimpulan dari penelitian ini adalah, ada hubungan positif signifikan antara dimensi big five personality dengan pemaafan pada penyintas KSDB. Skor faktor big five personality dan pemaafan KSDB berada pada kategori tinggi, dan individu mampu belajar memaafkan serta berdamai dengan kisah buruk yang pernah ia alami, sehingga pemaafan merupakan bentuk pemulihan psikologis yang bisa membantu individu untuk mencapai kesehatan mental di berbagai aspek kehidupan.

Hasil penelitian ini dapat dijadikan sebagai informasi bagi generasi muda era digital, supaya dalam membangun hubungan berpacaran dapat berkomitmen terhadap pasangannya, dan semaksimal mungkin menghindari perilaku-perilaku yang berdampak buruk pada kelangsungan hubungan seperti tindak kekerasan, dan saling menerima kelebihan serta kekurangan yang ada pada diri pasangan dengan menerapkan konsep cinta kasih yang holistik. Hal ini dimaksud, agar nantinya saat membangun hubungan yang lebih dalam yakni keluarga, bisa mencapai kualitas hidup yang optimal. Selain itu, bagi setiap orang yang merasa diri menjadi korban kekerasan dalam berpacaran, untuk terus belajar dan melatih diri melihat kebermaknaan hidup dan membangun kekuatan diri yang positif, serta mendorong diri mengikuti layanan psikologi 
ataupun pastoral yang bisa memfasilitasi diri memulihkan keadaan yang membahayakan, sehingga akan lebih mudah baginya untuk bereksistensi di kehidupan sehari-hari.

Penelitian ini hanya terbatas bagi penyintas KSDB yang telah melalui proses layanan konseling psikologi ataupun pastoral, sehingga masih belum menjangkau secara keseluruhan individu-individu yang menjadi korban KSDB, yang sedang berjuang dengan berbagai cara untuk bisa bangkit serta berdamai dengan kisah buruk KSDBnya. Maka dari itu, penelitian selanjutnya diharapkan bisa lebih memperluas cakupan variabel, maupun analisis KSDB secara mendalam dari pengalaman awal sampai pada proses pemulihan korban. Selain itu, penelitian selanjutnya disarankan dapat membuat program-program intervensi psikologi secara praktis dan sederhana, yang nantinya bisa dilakukan oleh setiap orang yang menjadi korban kekerasan, guna untuk pemulihan psikologisnya.

\section{Daftar Pustaka}

Abid, M., Shafiq, S., Naz, I., \& Riaz, M. (2015). Relationship between personality factor and level of forgiveness among college students. International Journal of Humanities and Social Science, 5(7), 149-154.

Azwar, S. (2012). Penyusunan skala psikologi. (edisi ke-2). Yogyakarta : Pustaka Pelajar.

Balliet, D. (2010). Conscientiousness and forgivingness : A meta-analysis. Personality and Individual Differences, 48(3), 259-263. https://doi.org/10.1016/j. paid.2009.10.021.

Berk, L. E. (2014). Development through the lifespan. (6 $6^{\text {th }}$ edition). USA : Pearson Education, Inc.

Bhattacharyya, A., Suresh, A., \& Joan, T. S. (2015). Personality predictors of polychronicity among young adults. Global Journal of Human Social Science : A Arts and Humanities Psychology, 15(2), 42-51.
Borrajo, E., Guadix, M. G., \& Calvete, E. (2015). Justification beliefs of violence, myths about love and cyber dating abuse. Psicothema, 27(4), 327-333. doi:10.7334/psicothema2015.59.

Chung, D. (2007). Making meaning of relationships : Young women's experience and understandings of dating violence. Journal of Violence Against Women's, 13(12), 1274-1295. doi:10.1177/1077801207310433.

Chung, M. S. (2016). Relation between lack of forgiveness and depression : The moderating effect of self-compassion. Psychological Reports, 119(3), 573-585. doi:10.1177/0033294116663520

Crandall, M., Schwab, J., Sheehan, K., \& Esposito, T. (2010). Illinois trauma centers and intimate partner violence are we doing our share ?. Journal of Family Social Work, 24, 2096-2108. doi: $10.1177 / 0886260508327702$.

Creswell, J. W. (2010). Desain penelitian : Pendekatan kualitatif, kuantitatif, dan campuran. Yogyakarta : PT. Pustaka Pelajar.

Farhadiasl, L., \& Pakdaman, S. (2016). The evaluation between love attitudes and sexual satisfaction to forgiveness in married employment of none private in shiraz city. International Journal of Humanities and Cultural Studies, 5, 690-704.

Feeney, J. A. (2011). Hurt feelings in couple relationships : Towards integrative models of the negative effects of hurtful events. Journal of Social and Personal Relationship, 21(4), 487-508. https:// doi.org/10.1177/0265407504044844.

Frankl, V. E. (1992). Mans search for meaning : An introduction to logotherapy. $\left(4^{\text {th }}\right.$ edition). Boston : Beacon Press.

Hafnidar. (2013). The relationship among five factor model of personality, spirituality, and forgiveness. International Journal of Social Science and Humanity, 3(2), 167170. doi:10.7763/IJSSH.2013.V3.220.

Hamby, S. (2017). On defining violence, and why matters. Psychology of Violence, 7(2), 167-180. doi:10.1037/vio0000117. 
Harmaini., \& Yulianti, A. (2014). Peristiwaperistiwa yang membuat bahagia. Psympathic: Jurnal IImiah Psikologi, 1(2), 109-119. doi:10.15575/psy. $\mathrm{v} 1 \mathrm{i} 2.472$.

Hays, D. G., Michel, R. E., Cole, R. F. Emelianchik, K., Forman, J., Lorelle, S., McBride, R., \& Sikes, A. (2011). A phenomenological investigation of adolescent dating relationships and dating violence counseling interventions. The Professional Counselor, 1(3), 222233. doi:10.15241/dgh.1.3.222.

Hurley, L., \& Weber, R. M. (2012). Conflict strategies and intimacy : Variations by romantis relationship development and gender. An International Journal on Personal Relationships, 6(2), 200-210. doi:10.5964/ijpr.v6i2.101.

Huwae, A. (2020). Analisis enam faktor preventifperilaku seksual berisiko remaja sekolah menengah pertama generasi platinum. Jurnal Psikohumanika, 12(2), 102-120. https://doi.org/10.31001/j.psi. v12i2.960.

John, O.P. (1990). The big-five factor taxonomy : Dimensions of personality in the natural language and questionnaires. In Pervin, L. A., \& John, O. P. (Eds.), Handbook of Personality: Theory and Research $\left(2^{\text {nd }}\right.$ edition. pp. 66-100). New York : Guilford Press.

Kaleta, K., \& Mroz, J. (2018). Personality traits and two dimensions of forgivingness. Roczniki Psychologiczne / Annals of Psychology, 21(2), 147-162. doi:10.18290/rpsych.2018.21.2-3.

Lijo, K. J. (2008). Forgiveness : Perspective, contexts and correlates. Journal of Psychology and Psychotherapy, 8(3), 1-5. doi:10.4172/2161-0487.1000342.

Marcus, R. F., \& Swett, B. (2003). Violence in close relationships: The role of emotion. Journal Aggression and Violent Behavior, 8, 313-327. doi:10.1016/ S1359-1789(01)00070-2.

McCrae, R. R., \& Costa, P. T. Jr. (1997). Personality trait structure as a human universal. American Psychologist, 52(5), 509-516. doi:10.1037/0003-
066X.52.5.509.

McCullough, M. E. (2000). Forgiveness as human strength : Theory, measurement, and links to well-being. Journal Social and Clinical Psychology, 19(1), 43-55. doi:10.1521/jscp.2000.19.1.43.

McCullough, M. E., \& Witvliet, C. V. O. (2001). Handbook of positive psychology: The psychology of forgiveness. UK : Oxford University Press.

McCullough, M. E., Worthington, E. L. Jr., \& Rachal, K. C. (1997). Interpersonal forgiving in close relationships. Journal of Personality and Social Psychology, 73(2), 321-336. https://doi. org/10.1037/0022-3514.73.2.321.

McDonell, J., Ott, J., \& Mitchell, M. (2010). Predicting dating violence victimization and perpetration among middle and high school students in a rural southern community. Children and Youth Services Review, 32(10), 1458-1463. doi:10.1016/j.childyouth.2010.07.001.

Muhid, A., Khariroh, L. M., Fauziyah, N., \& Andiarna, F. (2019). Quality of life perempuan penyintas kekerasan seksual : Studi kualitatif. Journal of Health Science and Prevention, 3(1), 47-55. doi.org/10.29080/jhsp.v3i1.185.

Munroe, M. (2004). Waiting and dating : A sensible guide to a fulfilling love relationship. USA : Bahamas Faith Ministry.

Murray, J. (2007). But I love him : Protecting your daughter from controlling, abusive dating relationship. New York: Harper Collins Publisher.

Natasya, G. Y., \& Susilawati, L. K. P. A. (2020). Pemaafan pada remaja perempuan yang mengalami kekerasan dalam pacaran. Psikobuletin : Buletin IImiah Psikologi, 1(3), 169-177. doi:10.24014/ pib.v\%vi\%i.9913.

National Commission on Violence Against Women. (2020, Maret 06). Kekerasan meningkat : Kebijakan penghapusan kekerasan seksual untuk membangun ruang aman bagi perempuan dan anak perempuan. Catatan Kekerasan Terhadap Perempuan 
Tahun 2019. Diakses dari http://www. komnasperempuan.go.id/file/pdf file/2020/.Catatan\%20Tahunan $\% 20$ Kekerasan \%20Terhadap\%20 Perempuan\%202020.pdf.

Nurifah, S. (2013, Mei 12). Tindak kekerasan tidak mesti berupa fisik, tapi juga sikap yang memaksa dan mengontrol dari pasangan anda. Jurnal Perempuan, 5. Diakses dari http://www. jurnalperempuan.org/kekerasan-dalampacaran.html.

Ohee, C., \& Purnomo, W. (2018). Pengaruh status hubungan berpacaran terhadap perilaku pacaran berisiko pada mahasiswa perantau asal Papua di kota Surabaya. The Indonesian Journal Public Health, 13(2), 268-280. doi:10.20473/ijph.vl13il.2018.268-280.

Pattiradjawane, C., Wijono, S., \& Engel, J. D. (2019). Uncovering violence occurring in dating relationship : An early study of forgiveness approach. Journal Psikodimensia, 18(1), 9-18. doi:10.24167/psidim.v18i1.1700.

Santrock, J. W. (2016). Adolescence. (16 ${ }^{\text {th }}$ edition). New York : McGraw-Hill Education.

Smith, M. E., Nunley, B., \& Martin, E. (2013). Intimate partner violance and the meaning of love. Issues in Mental Health Nursing, 34(6), 395-401. doi:10.3109/01 612840.2012.762960.

Susanti, R., Husni, D., \& Fitriyani, E. (2014). Perasaan terluka. Jurnal Psikologi, 10(2), 103-109. doi:10.24014/jp.v10i2.1188.

Ulfa, D. A. N. (2016). Hubungan kematangan emosi dan kebahagiaan pada remaja yang mengalami putus cinta. Jurnal Ilmiah Psikologi, 9(1), 92-99.

Walker, D. F., \& Gorsuch, R. L. (2002). Forgiveness within the big five personality model. Personality and Individual Differences, 32, 1127-1137. doi:10.1016/S0191-8869(00)00185-9.

Waring, M. H., \& Barraket, J. (2008). Dating and intimacy in the $21^{\text {st }}$ century : The use of online dating sites in Australia. International Journal of Emerging Technologies and Society, 6(1), 14-33.
World Health Organization. (2002, Oktober 3). Violence and health fact sheet No. 239 Tahun 2002. World Health Assembly : The United Nations High Commission on Human Rights and The African Union. Diakses dari http://www.who.int/ mediacentre/factsheets/fs239/en/.

Worthington, E. L. Jr., \& Wade, N. G. (1999). The psychology of unforgiveness and forgiveness and implications for clinical practice. Journal of Social and Clinical Psychology, 18(4), 385-418. doi:10.1521/jscp.1999.18.4.385.

Zahab, H., Dharmawan, Y., \& Winarni, S. (2017). Hubungan antara perilaku pacaran remaja dan pernikahan di bawah usia 20 tahun terhadap angka kelahiran menurut kelompok umur 1519 tahun di Indonesia. Jurnal Kesehatan Masyarakat (Undip), 5(3), 56-65. 